Article 134

Received: May 20, 2017

Accepted: June 16, 2017
Journal of Electrical Engineering and Information Technologies, Vol. 2, No. 1, pp. 15-23 (2017)

In print: ISSN $2545-4250$

On line: ISSN 4245-4269

UDC: 621.317:378.091.6]:006.91.067(497.7:496.5)

\title{
QUALITY AND CONFIDENCE ASSURANCE IN ELECTRICAL QUANTITIES MEASUREMENTS - RESULTS OF FEIT-HTT INTER-LABORATORY COMPARISON
}

\author{
Marija Čundeva-Blajer ${ }^{1}$, Vladimir Dimčev ${ }^{1}$, Mare Srbinovska ${ }^{1}$, \\ Genc Gjergjani ${ }^{2}$, Dea Kuqi ${ }^{2}$, Erind Dollaku ${ }^{2}$ \\ ${ }^{1}$ Faculty of Electrical Engineering and Information Technologies, \\ "Ss. Cyril and Methodius" University in Skopje, \\ Rugjer Bošković bb, P.O. box 574, 1001 Skopje, Republic of Macedonia \\ ${ }^{2}$ HTT - High Tech Test shpk, Perlat Rexhepi str. No. 6, Tirana, R. Albania \\ mcundeva@feit.ukim.edu.mk
}

\begin{abstract}
A b s t r a c t: According to ISO/IEC 17025 a laboratory shall have quality control procedures for monitoring the validity of tests and calibrations undertaken, through participation in inter-laboratory comparisons (ILC) or proficiency testing programmes (PT). This practice should be a periodic activity and in accordance with the international standards. In the paper the results of the international ILC conducted by the Laboratory of Electrical Measurements (LEM) of the Faculty of Engineering and Information Technologies at the Ss. Cyril and Methodius University in Skopje, R. Macedonia (pilot laboratory), and the High Tech Test shpk - Tirana, R. Albania (HTT), both accredited laboratories, will be presented. The ILC accomplished in the period March-April 2017 was conducted through calibration of $6 \frac{1}{2}$ digital multimeter Keysight 34401A for various electrical quantities. In the paper, the detailed measurement procedure followed by the two laboratories as well as the evaluation and acceptance criteria will be given. The results of the ILC will be presented and discussed. The ILC gives a significant contribution the quality and confidence assurance in electrical quantities measurements at national and regional/international level.
\end{abstract}

Key words: inter-laboratory comparison; proficiency testing; calibrations; metrology of electrical quantities; quality assurance

\section{ОБЕЗБЕДУВАЊЕ КВАЛИТЕТ И ДОВЕРБА ВО МЕРЕЊАТА НА ЕЛЕКТРИЧНИ ВЕЛИЧИНИ - РЕЗУЛТАТИ ОД МЕЃУЛАБОРАТОРИСКА СПОРЕДБА МЕЃУ ФЕИТ И ХТТ -}

А п с т р а к т: Според меѓународниот стандард ISO/IEC 17025 секоја лабораторија мора да има процедури за контрола на квалитет и мониторинг заради валидација на спроведените испитувања и калибрации. Тоа се реализира преку учество во меѓулабораториски споредби (МЛС) или програми за тестирање на оспособеноста (ТО). Оваа пракса треба да претставува периодична лабораториска активност спроведувана сообразно со меѓународни стандарди. Во трудот се презентирани резултатите од меѓународната меѓулабораториска споредба спроведена меѓ Лабораторијата за електрични мерења (ЛЕМ) при Факултетот за електротехника и инфромациски технологии (ФЕИТ) при Универзитетот „Св. Кирил и Методиј“ во Скопје (УКИМ), Р. Македонија, и High Tech Tests shpk (ХTT) од Тирана, Р. Албанија, , двете акредитирани лаборатории. Меѓулабораториската споредба е спроведена во периодот март-април 2017 година преку калибрација на 61/2 дигитален мултиметар Keysight 34401A за различни електрични величини. Во трудот е елаборирана деталната мерна постапка следена од страна на двете лаборатории, како и критериумите за оцена и прифатливост на добиените резултати од МЛС. Резултатите од МЛС се прикажани и дискутирани во трудов. Оваа МЛС дава значаен придонес кон обезбедувањето квалитет и доверба во мерењата на електричните величини на национално, регионално, како и меѓународно ниво.

Клучни зорови: меѓулабораториска споредба; тестирање на оспособеноста; калибрации; метрологија на електрични величини; обезбедување квалитет 


\section{INTRODUCTION}

According to ISO/IEC 17025 [1] a laboratory shall have quality control procedures for monitoring the validity of tests and calibrations undertaken [2]. This monitoring may include the participation in interlaboratory comparisons or proficiency testing programmes. Other means may include regular use of reference materials, or replicate tests, or calibrations using the same or different methods. By these mechanisms a laboratory can provide evidence of its competence to its clients, interested parties and the accreditation body.

Proficiency testing (PT) is the evaluation of participant performance against pre-established criteria by means of interlaboratory comparisons as defined in ISO/IEC 17043:2010, [3]. Interlaboratory comparison (ILC) is the organization, performance and evaluation of measurements or tests on the same or similar items by two or more laboratories or inspection bodies in accordance with pre-determined conditions [3].

Accreditation bodies (ABs) seeking to sign or seeking to maintain their status as a signatory to the ILAC Multilateral Recognition Arrangement (MRA) shall demonstrate the technical competence of their accredited calibration and testing laboratories and inspection bodies [2]. One of the elements by which accredited laboratories can demonstrate technical competence is by satisfactory participation in PT activities where such activities are available and appropriate. Where relevant, this also holds for accredited inspection bodies. Technical competence can also be demonstrated by successful participation in interlaboratory comparisons that have been organized for purposes other than PT in its strictest sense. Interlaboratory comparisons are widely used for a number of purposes and their use is increasing internationally [3]. Typical purposes for interlaboratory comparisons include [3]:

a) Evaluation of the performance of laboratories for specific tests or measurements and monitoring laboratories' continuing performance;

b) Identification of problems in laboratories and initiation of actions for improvement which, for example, may be related to inadequate test or measurement procedures, effectiveness of staff training and supervision, or calibration of equipment;

c) Establishment of the effectiveness and comparability of test or measurement methods;

d) Provision of additional confidence to laboratory customers; e) Identification of interlaboratory differences;

f) Education of participating laboratories based on the outcomes of such comparisons;

g) Validation of uncertainty claims;

h) Evaluation of the performance characterristics of a method - often described as collaborative trials;

i) Assignment of values to reference materials and assessment of their suitability for use in specific test or measurement procedures;

j) Support for statements of the equivalence of measurements of National Metrology Institutes through "key comparisons" and supplementary comparisons conducted on behalf of the International Bureau of Weights and Measurement (BIPM) and associated regional metrology orga-nizations [11] (http://kcdb.bipm.org/).

The international standard ISO/IEC 17043, [3], specifies general requirements for the competence of providers of proficiency testing schemes and for the development and operation of proficiency testing schemes. It defines the technical requirements:

- personnel,

- equipment, accommodation, environment,

- design of PT schemes,

- choice of method or procedure,

- operation of PT schemes,

- data analysis and evaluation of results,

- content of reports,

- communication with participants,

- confidentiality.

The standard [3] also comprises the management requirements, which are present in the general ISO standards for quality assurance.

Interlaboratory studies in measurement science, including key comparisons, and meta-analyses in several fields, including medicine, serve to intercompare measurement results obtained independently, and typically produce a consensus value for the common measurend that blends the values measured by the participants [12]. Since interlaboratory studies and meta-analyses reveal and quantify differences between measured values, regardless of the underlying causes for such differences, they also provide so-called 'top-down' evaluations of measurement uncertainty. Measured values are often substantially over-dispersed by comparison with their individual, stated uncertainties, thus suggesting the existence of yet unrecognized sources of uncertainty (dark uncertainty). In [12], six guiding principles are given for model-based 
approaches that expose and facilitate the critical assessment of validating assumptions, and give preeminence to substantive criteria to determine which measurement results to include, and which to exclude, as opposed to purely statistical considerations, and also how to weigh them. Following an overview of maximum likelihood methods, three general purpose procedures for data reduction are described in [12] implemented and made widely accessible in a Web-based application (NIST Consensus Builder), [12].

In [13], the problem of determining the combined result and its associated uncertainty in the measurement of a common measurand by a group of competent laboratories is addressed. Most data analyses of interlaboratory evaluations are based on the assumption that the expected values of the individual laboratory results are all equal to the value of the common measurand, and the laboratory results are subject to random effects only with respect to the value of the measurand. This assumption is frequently unjustified [13]. In [13] a more realistic assumption that the laboratory results are subject to both random and systematic effects with respect to the value of the measurand is taken and the value of the measurand may fall anywhere within the range of results. Therefore, a combined result and its associated standard uncertainty that place a non-negligible fraction of the results outside the 2-standard-uncertainty interval are unsatisfactory representations of the value of the common measurand provided by the set of laboratory results. The more realistic assumption requires dealing with the uncertainty arising from possible systematic effects in the laboratory results. Following the approach of the ISO Guide, in [13] a three-step method for determination of a combined result and its associated standard uncertainty such that the 2-standard-uncertainty interval including a sufficiently large fraction of the results is proposed. In [13] it is suggested that when ILC is performed the combined result and its associated standard uncertainty determined by the three-step method to be identified with the key comparison reference value and its associated standard uncertainty. These quantities can then be used to specify the degree of equivalence of the individual laboratory results.

The degrees of equivalence can be viewed as possibly the main result in the analysis of key comparison data, [14]. Their specification as given in the CIPM MRA is discussed and critically assessed in [14]. As argued in [14] there is an ambiguity in the definition and meaning of the (unilat- eral) degrees of equivalence. As a consequence of this ambiguity uncertainties quoted for (unilateral) degrees of equivalence may be questioned. The ambiguity can be avoided by identifying the quantities that are being estimated by the degrees of equivalence, and in [14] a standard statistical model to do this is proposed.

In this contribution, the results of the international ILC conducted by the Laboratory of Electrical Measurements (LEM) of the Faculty of Engineering and Information Technologies (FEIT) at the Ss. Cyril and Methodius University in Skopje (UKIM) (pilot laboratory), R. Macedonia and the High Tech Test shpk (HTT), Tirana, R. Albania, conducted in the period March-April 2017 following the standard ISO/IEC 17043 [3], are presented. In 2015 the LEM has accomplished the process of establishment of laboratory quality management system, and on 23.11.2015 was granted an accreditation according to the international standard EN ISO/IEC 17025 [1], by the Institute of Accreditation of R. Macedonia (IARM) with accreditation certificate LC-012. The HTT is the first calibration laboratory jointly accredited on 26.10 .2015 by the IARM, accreditation certificate LC-011, and the Albanian Directorate of Accreditation (DA) with accreditation certificate LK-001. The purpose of this inter-laboratory comparison is to compare the results obtained at the Laboratory for Electrical Measurements (LEM) at the Faculty of Electrical Engineering and Information Technologies of the Ss. Cyril and Methodius University in Skopje, R. Macedonia, and the High Tech Tests (HTT) from Tirana, Albania, for the calibration of $6 \frac{1}{2}$ digit Keysight 34401A digital multimeter (DMM).

\section{INTER-COMPARISON SPECIFICATIONS}

\section{A) ILC procedure}

The ILC procedure is designed according to the international standard ISO/IEC 17043 [3].

The laboratories had a period of one week to perform the measurement calibration procedure and one more week to submit the measurement results to the pilot laboratory. The measurement results are submitted by e-mail. The both laboratories are accredited according to ISO 17025:2005 for the following quantities:

$$
\begin{aligned}
& \text { - DC voltage, } \\
& \text { - DC current, } \\
& \text { - AC voltage, }
\end{aligned}
$$


- AC current,

- resistance.

Therefore the ILC measurement points are selected as given in Table 1.

Table 1

ILC measurement points

\begin{tabular}{|c|c|c|}
\hline Function & $\begin{array}{l}\text { DMM } \\
\text { Range }\end{array}$ & Measurement points \\
\hline \multirow{5}{*}{ DC voltage } & $100 \mathrm{mV}$ & $100 \mathrm{mV}$ \\
\hline & $1 \mathrm{~V}$ & $1 \mathrm{~V}$ \\
\hline & $10 \mathrm{~V}$ & $10 \mathrm{~V}, 0 \mathrm{~V},-10 \mathrm{~V}$ \\
\hline & $100 \mathrm{~V}$ & $+100 \mathrm{~V}$ \\
\hline & $1000 \mathrm{~V}$ & $+1000 \mathrm{~V}$ \\
\hline \multirow{3}{*}{ AC voltage } & $100 \mathrm{mV}$ & 100 mV@50 Hz,100 mV@1 kHz \\
\hline & $10 \mathrm{~V}$ & $\begin{array}{l}10 \mathrm{~V} @ 50 \mathrm{~Hz}, 10 \mathrm{~V} @ 1 \text { kHz, } \\
10 \mathrm{~V} @ 100 \mathrm{kHz}\end{array}$ \\
\hline & $100 \mathrm{~V}$ & $100 \mathrm{~V} @ 50 \mathrm{~Hz}, 100 \mathrm{~V} @ 1$ kHz \\
\hline \multirow{3}{*}{ DC Current } & $10 \mathrm{~mA}$ & $10 \mathrm{~mA}$ \\
\hline & $100 \mathrm{~mA}$ & $+100 \mathrm{~mA}, 0 \mathrm{~mA},-100 \mathrm{~mA}$ \\
\hline & $1 \mathrm{~A}$ & $1 \mathrm{~A}$ \\
\hline \multirow{3}{*}{$\mathrm{AC}$ current } & $10 \mathrm{~mA}$ & $10 \mathrm{~mA} @ 50 \mathrm{~Hz}, 10 \mathrm{~mA} @ 1 \mathrm{kHz}$ \\
\hline & $100 \mathrm{~mA}$ & $\begin{array}{l}100 \mathrm{~mA} @ 50 \mathrm{~Hz}, 100 \mathrm{~mA} @ 1 \mathrm{kHz}, \\
100 \mathrm{~mA} @ 5 \mathrm{kHz}\end{array}$ \\
\hline & $1 \mathrm{~A}$ & $1 \mathrm{~A} @ 50 \mathrm{~Hz}, 1 \mathrm{~A} @ 1 \mathrm{kHz}$ \\
\hline \multirow{3}{*}{ Resistance } & $1 \mathrm{k} \Omega$ & $1 \mathrm{k} \Omega$ \\
\hline & $10 \mathrm{k} \Omega$ & $10 \mathrm{k} \Omega$ \\
\hline & $1 \mathrm{M} \Omega$ & $1 \mathrm{M} \Omega$ \\
\hline
\end{tabular}

The measuring device was transported by car by HTT from Tirana - Albania, to Skopje and back. During the measurement procedure and during the transport of the measuring device, each of the participants took care in preventing damage, not to overheat and so on.

\section{B) ILC time-schedule}

The ILC has started on March $6^{\text {th }} 2017$ when the artifact was delivered to LEM. The calibration measurement procedure was accomplished within three weeks. From the $6^{\text {th }}$ to the $20^{\text {th }}$ of March 2017 the measurements were performed by the pilot laboratory of the LEM. On the $20^{\text {th }}$ of March 2017 the artifact of calibration and ILS, was transported back from LEM in Skopje to HTT in Tirana. In the period from the $21^{\text {st }}$ to $31^{\text {st }}$ of March 2017 the measurements were conducted by the HTT. The final results taken at the HTT were used to submit to LEM on the $1^{\text {st }}$ of April 2017 and are presented in the ILC final report [19]. The preparation of the final report lasted from $1^{\text {st }}$ to $10^{\text {th }}$ of April 2017.

\section{C) ILC artefact of calibration - DMM specifications}

The owner of the $6 \frac{1}{2}$ digit Keysight 34401A DMM used as an artifact of calibration in this inter-laboratory comparison is HTT. In Table 2 the main DMM specifications are given.

Table 2

DMM specifications

\begin{tabular}{lll}
\hline \hline Measuring device: & \multicolumn{2}{l}{ Digital multimeter } \\
\hline $\begin{array}{l}\text { Manufacturer: } \\
\text { Model: }\end{array}$ & Keysight & \\
Serial number: & $967361 \mathrm{~A}$ & \\
\hline & DC voltage: & 5 ranges: $100 \mathrm{mV}$ to $1000 \mathrm{~V}$ \\
& AC voltage: & 5 ranges: $100 \mathrm{mV}$ to $1000 \mathrm{~V}$ \\
& & $3 \mathrm{~Hz}$ to $300 \mathrm{kHz}$ \\
Measurement & DC current: & 4 ranges: $10 \mathrm{~mA}$ to $1 \mathrm{~A}$ \\
ranges & AC current: & 4 ranges: $100 \mathrm{~mA}$ to $1 \mathrm{~A}$ \\
& & $3 \mathrm{~Hz}$ to $10 \mathrm{kHz}$ \\
& Resistance: & 4 ranges: $10 \Omega$ to $1 \mathrm{M} \Omega$ \\
\hline \hline
\end{tabular}

\section{D) Equipment used by the ILC participants}

During the ILC measurement procedure the LEM has used the FLUKE 5500A as a reference generator and the $81 / 2$ digit Agilent DMM as a reference indicator with specifications given in Table 3.

Table 3

LEM reference calibration indicator

\begin{tabular}{ll}
\hline \hline Manufacturer & Agilent \\
\hline Model & 3458A \\
$\begin{array}{l}\text { Serial number } \\
\text { Calibrated by } 45049520 \\
\text { Tehnički opitni centar, Sektor za } \\
\text { metrologiju, Beograd }\end{array}$ \\
$\begin{array}{l}\text { Calibration } \\
\text { certificate No }\end{array}$ & $\begin{array}{l}\text { standards of Directorate of Measures and } \\
\text { Precious Metals (NMI of R. Serbia) and }\end{array}$ \\
$\begin{array}{l}\text { Calibration } \\
\text { date }\end{array}$ & 2.9.2013 \\
\hline \hline
\end{tabular}


The HTT has used the FLUKE 5522A A as a reference generator and indicator with specifications given in Table 4 .

Table 4

HTT reference calibration indicator

\begin{tabular}{ll}
\hline \hline Manufacturer & Fluke \\
Model & 5522A \\
Serial number & 3324901 \\
$\begin{array}{l}\text { Calibrated by } \\
\text { Calibration } \\
\text { certificate No }\end{array}$ & Fluke \\
Falibration date & 16.11 .2015 \\
\hline \hline
\end{tabular}

\section{E) ILC environmental conditions}

Measurements were done according to the laboratories' accredited DMM calibration procedures. During the measurements the user manual from the manufacturer was used. Standard ambient conditions were:

- temperature: $23 \pm 1{ }^{\circ} \mathrm{C}$

- humidity: $45 \pm 10 \%$ rh

\section{ILC STATISTICAL METHOD}

PT or ILC results can appear in many forms, spanning a wide range of data types and underlying statistical distributions [3]. The statistical methods used to analyze the results need to be appropriate for each situation [3]. The fundamental steps for statistical data processing common to nearly all PT and ILC are:

a) determination of the assigned value;

b) calculation of performance statistics;

c) evaluation of performance, and

d) preliminary determination of PT/ILC item homogeneity and stability.

PT/ILC results often need to be transformed into a performance statistic, in order to aid interpretation and to allow comparison with defined objectives. The purpose is to measure the deviation from the assigned value in a manner that allows comparison with performance criteria. Statistical methods may range from no processing required to complex statistical transformations [12-18]. Performance statistics should be meaningful to participants. Therefore, statistics should be appropri- ate for the relevant tests and be well understood or traditional within a particular field. Commonly used statistics for quantitative results are presented as follows.

The difference, $D$, is calculated as:

$$
D=x-X
$$

where $x$ is the participant's result, and $X$ is the assigned value. The percent difference, $D \%$, is calculated as:

$$
D_{0}=\frac{x-X}{x} \cdot 100 .
$$

The $\mathrm{z}$ scores are calculated as:

$$
z=\frac{x-X}{\hat{\sigma}} \cdot 100,
$$

where $\hat{\sigma}$ is the standard deviation for PT/ILC assessment. $\hat{\sigma}$ can be calculated from the following:

- a fitness for purpose goal for performance, as determined by expert judgement or regulatory mandate (prescribed value);

- an estimate from previous rounds of proficiency testing or expectations based on experience (by perception);

- an estimate from a statistical model (general model);

- the results of a precision experiment; or

- participant results, i.e. a traditional or robust standard deviation based on participant results.

The zeta score, $\zeta$, is calculated as in (4), where calculation is very similar to the $E_{n}$ number (5), except that standard uncertainties are used rather than expanded uncertainties. This allows the same interpretation as for traditional $z$ scores.

$$
\zeta=\frac{x-X}{\sqrt{u_{l a b}^{2}+u_{a v}^{2}}},
$$

where $u_{l a b}$ is the combined standard uncertainty of a participant's result and $u_{a v}$ is the standard uncertainty of the assigned value (Tablr 5).

The $E_{n}$ numbers are calculated as:

$$
E_{n}=\frac{x-X}{\sqrt{u_{\text {lab }}^{2}+u_{r e f}^{2}}},
$$

where $u_{l a b}$ is the expanded uncertainty of a participant's result and $u_{r e f}$ is the expanded uncertainty of the reference laboratory's assigned value. 
Table 5

ILC referent values

\begin{tabular}{|c|c|c|c|c|}
\hline Function & $\begin{array}{l}\text { Applied } \\
\text { value }\end{array}$ & Range & $\begin{array}{l}\text { Reference } \\
\text { error }\end{array}$ & $\begin{array}{l}\text { Reference } \\
\text { uncertainty }\end{array}$ \\
\hline \multirow{7}{*}{ DCV } & $100 \mathrm{mV}$ & $100 \mathrm{mV}$ & $-14.2 \mu \mathrm{V} / \mathrm{V}$ & $9.12 \mu \mathrm{V} / \mathrm{V}$ \\
\hline & $1 \mathrm{~V}$ & $1 \mathrm{~V}$ & $-13.0 \mu \mathrm{V} / \mathrm{V}$ & $3.43 \mu \mathrm{V} / \mathrm{V}$ \\
\hline & $10 \mathrm{~V}$ & $10 \mathrm{~V}$ & $-4.5 \mu \mathrm{V} / \mathrm{V}$ & $0.33 \mu \mathrm{V} / \mathrm{V}$ \\
\hline & $0 \mathrm{~V}$ & $10 \mathrm{~V}$ & $-1.0 \mu \mathrm{V}$ & $0.28 \mu \mathrm{V}$ \\
\hline & $-10 \mathrm{~V}$ & $10 \mathrm{~V}$ & $-2.0 \mu \mathrm{V} / \mathrm{V}$ & $0.33 \mu \mathrm{V} / \mathrm{V}$ \\
\hline & $100 \mathrm{~V}$ & $100 \mathrm{~V}$ & $5.7 \mu \mathrm{V} / \mathrm{V}$ & $4.06 \mu \mathrm{V} / \mathrm{V}$ \\
\hline & $1000 \mathrm{~V}$ & $1000 \mathrm{~V}$ & $2.7 \mu \mathrm{V} / \mathrm{V}$ & $43.86 \mu \mathrm{V} / \mathrm{V}$ \\
\hline \multirow{7}{*}{$\mathrm{ACV}$} & $100 \mathrm{mV}, 50 \mathrm{~Hz}$ & $100 \mathrm{mV}$ & $-0.2 \mathrm{mV} / \mathrm{V}$ & $\mathrm{nV} / \mathrm{V}$ \\
\hline & $100 \mathrm{mV}, 1 \mathrm{kHz}$ & $100 \mathrm{mV}$ & $-0.2 \mathrm{mV} / \mathrm{V}$ & $0.08 \mathrm{mV} / \mathrm{V}$ \\
\hline & $10 \mathrm{~V}, 50 \mathrm{~Hz}$ & $10 \mathrm{~V}$ & $-0.2 \mathrm{mV} / \mathrm{V}$ & $0.07 \mathrm{mV} / \mathrm{V}$ \\
\hline & $10 \mathrm{~V}, 1 \mathrm{kHz}$ & $10 \mathrm{~V}$ & $-0.2 \mathrm{mV} / \mathrm{V}$ & $0.07 \mathrm{mV} / \mathrm{V}$ \\
\hline & $10 \mathrm{~V}, 100 \mathrm{kHz}$ & $10 \mathrm{~V}$ & $0.6 \mathrm{mV} / \mathrm{V}$ & $0.07 \mathrm{mV} / \mathrm{V}$ \\
\hline & $100 \mathrm{~V}, 50 \mathrm{~Hz}$ & $100 \mathrm{~V}$ & $-0.1 \mathrm{mV} / \mathrm{V}$ & $0.08 \mathrm{mV} / \mathrm{V}$ \\
\hline & $100 \mathrm{~V}, 1 \mathrm{kHz}$ & $100 \mathrm{~V}$ & $-0.2 \mathrm{mV} / \mathrm{V}$ & $0.08 \mathrm{mV} / \mathrm{V}$ \\
\hline \multirow{5}{*}{ DCI } & $10 \mathrm{~mA}$ & $10 \mathrm{~mA}$ & $0.02 \mathrm{~mA} / \mathrm{A}$ & $0.05 \mathrm{~mA} / \mathrm{A}$ \\
\hline & $100 \mathrm{~mA}$ & $100 \mathrm{~mA}$ & $0.04 \mathrm{~mA} / \mathrm{A}$ & $0.04 \mathrm{~mA} / \mathrm{A}$ \\
\hline & $0 \mathrm{~mA}$ & $100 \mathrm{~mA}$ & $40 \mu \mathrm{A}$ & $42 \mu \mathrm{A}$ \\
\hline & $-100 \mathrm{~mA}$ & $100 \mathrm{~mA}$ & $0.01 \mathrm{~mA} / \mathrm{A}$ & $0.04 \mathrm{~mA} / \mathrm{A}$ \\
\hline & $1 \mathrm{~A}$ & $1 \mathrm{~A}$ & $0.03 \mathrm{~mA} / \mathrm{A}$ & $0.7 \mathrm{~mA} / \mathrm{A}$ \\
\hline \multirow{7}{*}{ ACI } & $10 \mathrm{~mA}, 50 \mathrm{~Hz}$ & $10 \mathrm{~mA}$ & $0.07 \mathrm{~mA} / \mathrm{A}$ & $0.05 \mathrm{~mA} / \mathrm{A}$ \\
\hline & $10 \mathrm{~mA}, 1 \mathrm{kHz}$ & $10 \mathrm{~mA}$ & $-0.02 \mathrm{~mA} / \mathrm{A}$ & $0.49 \mathrm{~mA} / \mathrm{A}$ \\
\hline & $100 \mathrm{~mA}, 50 \mathrm{~Hz}$ & $100 \mathrm{~mA}$ & $0.03 \mathrm{~mA} / \mathrm{A}$ & $0.39 \mathrm{~mA} / \mathrm{A}$ \\
\hline & $100 \mathrm{~mA}, 1 \mathrm{kHz}$ & $100 \mathrm{~mA}$ & $0.05 \mathrm{~mA} / \mathrm{A}$ & $0.39 \mathrm{~mA} / \mathrm{A}$ \\
\hline & $100 \mathrm{~mA}, 5 \mathrm{kHz}$ & $100 \mathrm{~mA}$ & $-0.08 \mathrm{~mA} / \mathrm{A}$ & $0.39 \mathrm{~mA} / \mathrm{A}$ \\
\hline & $1 \mathrm{~A}, 50 \mathrm{~Hz}$ & $1 \mathrm{~A}$ & $0.07 \mathrm{~mA} / \mathrm{A}$ & $7.78 \mathrm{~mA} / \mathrm{A}$ \\
\hline & $1 \mathrm{~A}, 1 \mathrm{kHz}$ & $1 \mathrm{~A}$ & $0.07 \mathrm{~mA} / \mathrm{A}$ & $7.90 \mathrm{~mA} / \mathrm{A}$ \\
\hline \multirow{3}{*}{$\mathrm{R}$} & $1 \mathrm{k} \Omega$ & $1 \mathrm{k} \Omega$ & $-0.16 \mu \Omega / \Omega$ & $77.78 \mu \Omega / \Omega$ \\
\hline & $10 \mathrm{k} \Omega$ & $10 \mathrm{k} \Omega$ & $-0.02 \mu \Omega / \Omega$ & $0.78 \mu \Omega / \Omega$ \\
\hline & $1 \mathrm{M} \Omega$ & $1 \mathrm{M} \Omega$ & $0.03 \mu \Omega / \Omega$ & $77.78 \mu \Omega / \Omega$ \\
\hline
\end{tabular}

The relative error for every measurement point is:

$$
\varepsilon=\frac{S_{R E A D}-S_{A P P L}}{S_{A P P L}} \cdot 10^{6},
$$

where $S_{A P P L}$ is the applied value, and $S_{R E A D}$ is the measured value with the instrument.

For measurement null points, the absolute error can be calculated as:

$$
\varepsilon=S_{R E A D}-S_{A P P L} .
$$

The reference uncertainty is calculated as:

$$
u_{\text {ref }}=\sqrt{u_{\text {cerificate }}^{2}+\left(\frac{1}{2} u_{D M M}\right)^{2}},
$$

where, $u_{\text {certificate }}$ is the uncertainty of the reference standard from its calibration certificate, and $u_{D M M}$ is uncertainty of the calibration artifact, mainly introduced from its resolution.

\section{ILC RESULTS}

According to [3], graphical presentation of the ILC results is delivered, as described in ISO 13528 [17] and the IUPAC International Harmonized Protocol [18]. These charts can be used to show distributions of participant values. In the full ILC report [19], the graphical presentation is given for each measurement point. In the Figures 1-6, selected results at different measurement ranges derived from the measurements in the two participating laboratories are presented.

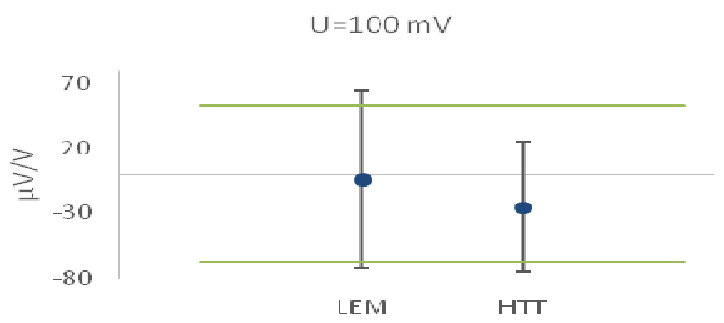

Fig. 1. Measurement point $U=100 \mathrm{mV}$ DC voltage, range $100 \mathrm{mV}$

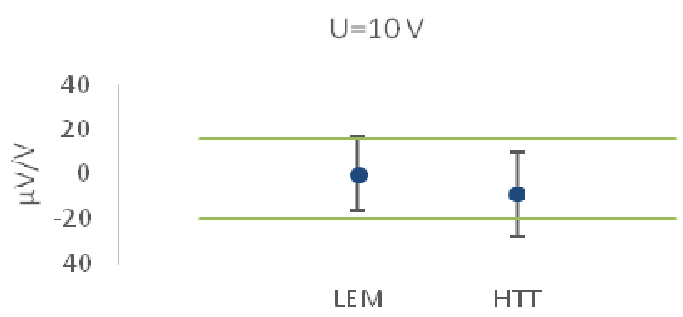

Fig. 2. Measurement point $U=10 \mathrm{~V}$ DC voltage, range $10 \mathrm{~V}$

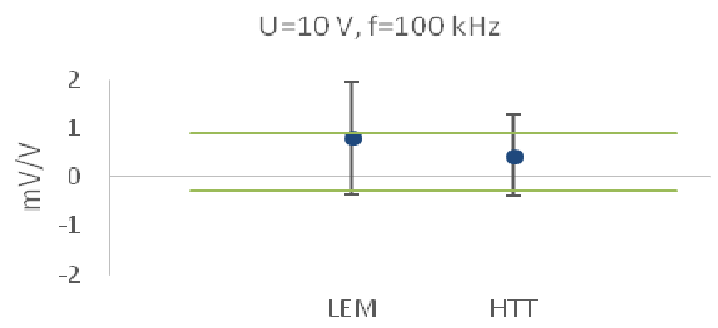

Fig. 3. Measurement point $U=10 \mathrm{~V}$ AC voltage @ $100 \mathrm{kHz}$, range $10 \mathrm{~V}$ 


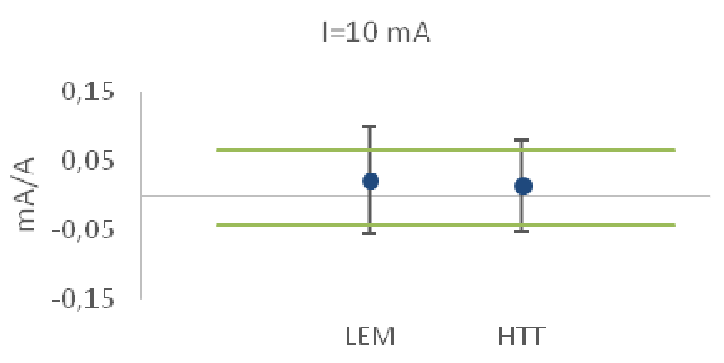

Fig. 4. Measurement point $I=10 \mathrm{~mA}$ DC current, range $10 \mathrm{~mA}$

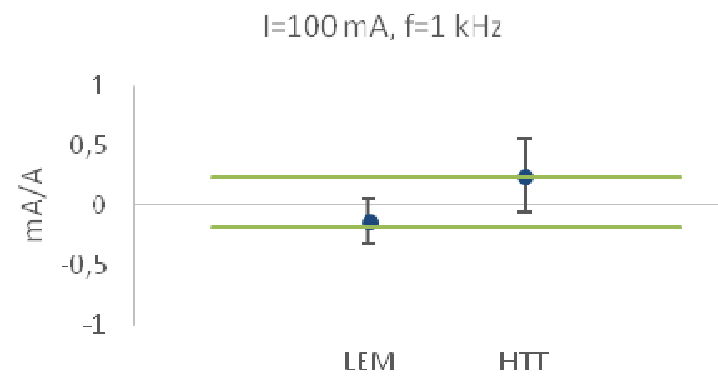

Fig. 5. Measurement point $I=100 \mathrm{~mA}$ AC current @ $1 \mathrm{kHz}$, range $100 \mathrm{~mA}$

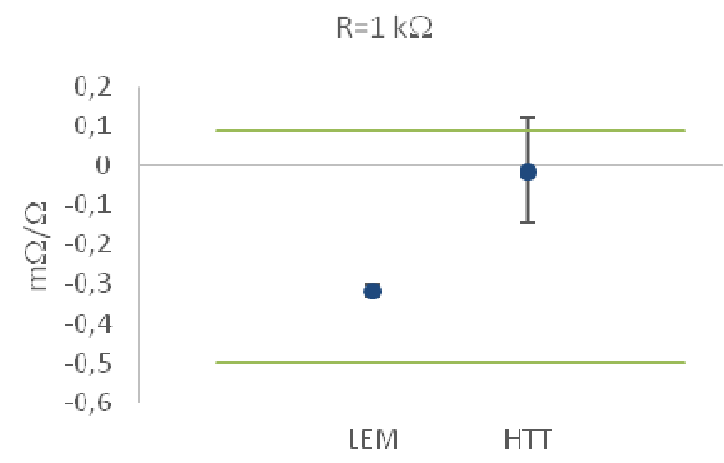

Fig. 6. Measurement point $R=1 \mathrm{k} \Omega$ resistance, range $1 \mathrm{k} \Omega$

\section{ILC EVALUATION OF PERFORMANCE METHODOLOGY AND ACCEPTANCE CRITERION}

In the ILC, criteria for performance evaluation are established after taking into account whether the performance measure involves certain features [3]. The features for performance evaluation are the following:

a) Expert consensus, where the advisory group or other qualified experts, directly determines whether reported results are fit for their intended purpose; agreement of experts is the typical way to assess results for qualitative tests. b) Fitness for purpose, predetermined criteria that consider, for example, method performance specifications and participants' recognized level of operation.

c) Statistical determination for scores, i.e. where criteria should be appropriate for each score; common examples of application of scores are as follows:

1) For $z$ scores and zeta scores (for simplicity, only " $z$ " is indicated in the examples below, but " $\zeta$ " may be substituted for " $z$ " in each case):

- $|z| \leq 2,0$ indicates "satisfactory" performance and generates no signal;

- 2,0<|z|<3,0 indicates "questionable" performance and generates a warning signal;

- $|z| \geq 3,0$ indicates "unsatisfactory" performance and generates an action signal.

2) For $E_{n}$ numbers:

- $\left|E_{\text {a }}\right| \leq 1,0$ indicates "satisfactory" performance and generates no signal;

- $\left|E_{\text {an }}\right|>1,0$ indicates "unsatisfactory" performance and generates an action signal.

\section{DISCUSSION OF THE ILC RESULTS}

In the FEIT-HTT ILC, as an evaluation criterion, the $E_{n}$ number is used:

$$
E_{n}=\frac{\varepsilon_{l a b}-\varepsilon_{r e f}}{\sqrt{u_{l a b}^{2}+u_{r e f}^{2}}},
$$

where $\varepsilon_{l a b}$ is the relative error declared by the participating laboratory, $\varepsilon_{r e f}$ is the referent relative error, $u_{\text {lab }}$ is the expanded measurement uncertainty $(k=2)$ of the participating laboratory, and $u_{r e f}$ is the expanded referent measurement uncertainty $(k=2)$. The evaluation criteria are based on calculation of the $E_{n}$ number, which is defined as:

$$
\begin{aligned}
& \left|E_{n}\right| \leq 1,0 \rightarrow \text { PASS, } \\
& \left|E_{n}\right|>1,0 \rightarrow \text { FAIL. }
\end{aligned}
$$

In Table 6, the values of the $E_{n}$ number for each measurement point and for both participating laboratories are given: 
Table 6

ILC results acceptance criteria according the $E_{n}$ number

\begin{tabular}{|c|c|c|c|c|}
\hline Function & \multicolumn{2}{|c|}{ Applied value } & $\begin{array}{c}\text { LEM-FEIT } \\
E_{n}\end{array}$ & $\begin{array}{c}\text { HTT } \\
E_{n}\end{array}$ \\
\hline \multirow{7}{*}{ DCV } & $100 \mathrm{mV}$ & & -0.2 & 0.0 \\
\hline & $1 \mathrm{~V}$ & & -0.3 & 0.1 \\
\hline & $10 \mathrm{~V}$ & & -0.3 & 0.2 \\
\hline & $0 \mathrm{~V}$ & & -0.5 & 0.1 \\
\hline & $-10 \mathrm{~V}$ & & -0.1 & 0.1 \\
\hline & $100 \mathrm{~V}$ & & 0.3 & -0.1 \\
\hline & $1000 \mathrm{~V}$ & & 0.0 & 0.0 \\
\hline \multirow{7}{*}{$\mathrm{ACV}$} & $100 \mathrm{mV}$ & $50 \mathrm{~Hz}$ & 0.4 & -1 \\
\hline & $100 \mathrm{mV}$ & $1 \mathrm{kHz}$ & 0.4 & -1 \\
\hline & $10 \mathrm{~V}$ & $50 \mathrm{~Hz}$ & 0.0 & 0.0 \\
\hline & $10 \mathrm{~V}$ & $1 \mathrm{kHz}$ & 0.1 & 0.0 \\
\hline & $10 \mathrm{~V}$ & $\begin{array}{r}100 \\
\mathrm{kHz}\end{array}$ & -0.2 & 0.2 \\
\hline & $100 \mathrm{~V}$ & $50 \mathrm{~Hz}$ & 0.3 & -0.7 \\
\hline & $100 \mathrm{~V}$ & $1 \mathrm{kHz}$ & 0.3 & -0.8 \\
\hline \multirow{5}{*}{ DCI } & $10 \mathrm{~mA}$ & & -0.1 & 0.1 \\
\hline & $100 \mathrm{~mA}$ & & 0.0 & 0.0 \\
\hline & $0 \mathrm{mV}$ & & 0.0 & 0.0 \\
\hline & $-100 \mathrm{~mA}$ & & -0.4 & 0.5 \\
\hline & $1 \mathrm{~A}$ & & 0.0 & 0.0 \\
\hline \multirow{7}{*}{$\mathrm{ACI}$} & $10 \mathrm{~mA}$ & $50 \mathrm{~Hz}$ & 0.4 & -0.1 \\
\hline & $10 \mathrm{~mA}$ & $1 \mathrm{kHz}$ & 0.2 & -0.1 \\
\hline & $100 \mathrm{~mA}$ & $50 \mathrm{~Hz}$ & 0.3 & -0.3 \\
\hline & $100 \mathrm{~mA}$ & $1 \mathrm{kHz}$ & 0.4 & -0.4 \\
\hline & $100 \mathrm{~mA}$ & $5 \mathrm{kHz}$ & 0.5 & -0.1 \\
\hline & $1 \mathrm{~A}$ & $50 \mathrm{~Hz}$ & 0.0 & 0.0 \\
\hline & $1 \mathrm{~A}$ & $1 \mathrm{kHz}$ & 0.0 & 0.0 \\
\hline \multirow{3}{*}{$\mathrm{R}$} & $1 \mathrm{k} \Omega$ & & -0.2 & 0.1 \\
\hline & $10 \mathrm{k} \Omega$ & & 0.1 & 0.0 \\
\hline & $1 \mathrm{M} \Omega$ & & 0.1 & 0.0 \\
\hline
\end{tabular}

According the calculated $E_{n}$ number and the graphical presentation of the ILC results, both participating laboratories LEM and HTT passed the inter-comparison evaluation criteria.

\section{CONCLUSION}

In the paper the results of a bilateral interlaboratory comparison in the field of calibration of electrical quantities between the Laboratory of Electrical Measurements at the Faculty of Electrical Engineering and Information Technologies at the Ss. Cyril and Methodius University in Skopje and the HTT-High Tech Tests shpk in Tirana are presented. The derived ILC results are satisfactory against the posed acceptance criteria for the both laboratories. Through this ILC the following is achieved:

- Quantified evaluation of the performance of the two laboratories in the process of calibration of electrical quantities and monitoring laboratories' continuing performance.

- Validation of the laboratories measurement procedures.

- Contribution to the staff training and supervision.

- Establishment of the comparability and unity of laboratories calibration methods.

- Increase of confidence in the laboratory results.

- Identification of interlaboratory differences which are in acceptable limits.

- Validation of laboratories' stated uncertainty.

The ILC participating laboratories play significant role in the national and regional metrology infrastructure in the field of electrical measurements. with a high number of calibrations performed for the conformity assessment bodies and industry. Therefore this ILC gives a significant contribution the quality and confidence assurance in electrical quantities measurements at national as well as regional level. The unity of the validated measurements through the ILC has also an international metrology impact.

\section{REFERENCES}

[1] ISO/IEC 17025:2005. General Requirements for the Competence of Testing and Calibration Laboratories.

[2] ILAC-P9:06/2014 - ILAC Policy for Participation in Proficiency Testing Activities.

[3] ISO/IEC 17043:2010. Conformity assessment - General requirements for proficiency testing.

[4] Regulation on Requirements for participation on Proficiency Testing. Inter-laboratory Comparisons and External 
Quality Assessment Programmes. IARM Procedure P06. Ver. 07. 2015.

[5] EA-4/18 TA: 2010 - Guidance on the level and frequency of proficiency testing participation.

[6] EA 03/04 G: 2001 - Use of Proficiency Testing as a Tool for Accreditation in Testing (with EUROLAB and EURACHEM). Reinstated according to EA Resolution 2012(29)24.

[7] EA INF 12: 2014 Benefits and importance of the participation in EA highlighted PT schemes.

[8] EA-2/14 M: 2008 - Procedure for Regional Calibration ILCs in Support of the EA-MLA.

[9] EA Inter-Laboratory Comparisons (previous EAL-P7);

[10] ILAC Guidelines G8 on Reporting of Compliance with Specification.

[11] http://kcdb.bipm.org/ (last access 29.06.2017).

[12] Koepke, A.. Lafarge, T.. Possolo, A. and Toman, B.: Consensus building for interlaboratory studies. key comparisons. and meta-analysis. Metrologia. Volume 54, Number 3, p. 29 (2017).

[13] Kacker, R.. Datla, R., Parr, A.: Combined result and associated uncertainty from interlaboratory evaluations based on the ISO Guide. Metrologia. Volume 39, Number 3, pp. 279-294 (2002).

[14] Elster, C., Toman, B.: Analysis of key comparison data: critical assessment of elements of current practice with suggested improvements. Metrologia. Volume 50, Number 5, pp. 549-556 (2013).

[15] Arsov, L., Čundeva-Blajer, M., Sala, A., Hegedus, H., Malaric, R.: Interlaboratory Comparison of the Electrical Reference Standards of FEIT - Skopje and FER Zagreb. $17^{\text {th }}$ IMEKO TC4 Int. Symp.. Košice. Slovakia. 8 10 September 2010, Paper No. 28, on CD ROM.

[16] Arsov, L., Sala, A., Čundeva-Blajer, M., Hegedus, H.: Interlaboratory Comparison of DC Voltage Reference Standards.. Зборник на трудови на 9. Национална конференција со меѓународно учество ETAI 2009. Охрид, Р. Македонија, 26-29 септември 2009 (CD ROM E2-5).

[17] ISO 13528:2015. Statistical methods for use in proficiency testing by interlaboratory comparison

[18] Thompson, M., Ellison, S., Wood, R.: The International Harmonized Protocol for the Proficiency Testing of Analytical Chemistry Laboratories, (IUPAC International Harmonized Protocol), Pure Appl. Chem.. Vol. 78, No. 1, pp. 145-196 (2006)

[19] Čundeva-Blajer, M., Dimčev, V., Srbinovska, M., Gergani, G., Kuqi, D., Dollaku, E.: Interlaboratory Comparison through Calibration of Calibration of $6^{1 / 2}$ Digital Multimeter. Report on Interlaboratory Comparison. Faculty of Electrical Engineering and Imations Techynology - Skopje, and High Tech Tests HTT - Tirana. R. Albania, April 2017. 
